\title{
Responsiveness of Rat Nonparenchymal Liver Cells and Spleen Cells to the Decomposition of Erythrocytes Exposed to Di-n-butyl Phthalate and Its Metabolite
}

\author{
Masamichi Fukuoka, ${ }^{*}$ Shingo Nimi, Yu Zhou, ${ }^{1)}$ Tetsu Kobayashi, and Takao Hayakawa \\ Division of Biological Chemistry, National Institute of Health Sciences, Kamiyoga-1-chome, Setagaya-ku, Tokyo 158, \\ Japan. Received February 21, 1996; accepted May 31, 1996
}

\begin{abstract}
We have reported that di-n-butyl phthalate (DBP) caused the depletion of circulating iron, characterized by the release of iron from both haemoglobin $(\mathrm{Hb})$ and transferrin (Tf). The present study investigated whether the erythrocytes from DBP-treated rats were destroyed by nonparenchymal liver cells (NPC, including Kupffer cells) or spleen cells (SC). In the in vivo study, there were observed depletions of $\mathrm{Hb}$ in the blood and of iron in the hepatic Tf fraction, as well as an accumulation of iron in the hepatic hemosiderin (Hs) and splenic Tf fractions. In the in vitro study, mono-butyl phthalate (MBP), a metabolite of DBP, caused a depletion of iron in the plasma Tf, although a direct release of iron from Tf was not detectable. When erythrocytes from DBP-treated rats and erythrocytes preincubated with MBP both were incubated with NPC, respectively, the Hb was decomposed and the iron also accumulated in the cell debris. However, when the two kinds of erythrocytes were incubated with SC, respectively, no decomposition of $\mathrm{Hb}$ was observed at low and medium doses, but the highest dose induced an accumulation of iron to Tf. Therefore, the NPC may contribute in part to the decomposition of DBP- or MBPaffected erythrocytes.
\end{abstract}

Key words phthalate; iron release; transferrin; haemoglobin; hemosiderin; nonparenchymal liver cell

It is well known that phthalates cause testicular damage. ${ }^{2-7)}$ Mechanisms of the damage were responsible for producing the Sertoli cell damage histologically ${ }^{2-13)}$ and biochemically. ${ }^{4-7,14-17)}$ Fukuoka et al. ${ }^{5,6,18,19)}$ and Zhou et $a .^{7)}$ proposed a possible mechanism, the loss of circulating iron, which could account for the Sertoli cell damage based on three phenomena: 1$)$ di- $n$-butyl phthalate (DBP) and its metabolite (mono-butyl phthalate (MBP)) induced the release of iron from haemoglobin $(\mathrm{Hb})$ during Heinz body formation in erythrocytes, 2) the release of iron from transferrin (Tf) was accelerated by the acidity of MBP and 3) the iron released was accumulated into the hemosiderin (Hs)-fraction of the liver. Therefore, it is necessary to explain the loss of circulating iron from the interactions of the three phenomena.

Naughton et $a l^{20)}$ have reported that senescent erythrocytes are selectively recognized and removed from the circulation by macrophages located primarily in the spleen and liver. Therefore, we investigated a loss of circulating iron from the effects of nonparenchymal liver cells (NPC) or spleen cells (SC) on DBP- or MBP-affected erythrocytes and $\mathrm{Tf}$, respectively.

\section{MATERIALS AND METHODS}

Chemicals DBP (purity 99.9\%) and assay kits for iron level were purchased from Wako Pure Chemical Ind. Ltd., (Tokyo).

MBP (purity 99.9\%) was synthesized by heating an equivalent mixture of phthalic anhydride and $n$-butyl alcohol at $120^{\circ} \mathrm{C}$ for $5 \mathrm{~h}$, according to the method of Brunel. ${ }^{21)}$

Rat Tf was purchased from Sigma. Horseradish peroxidase-goat anti-rabbit $\operatorname{IgG}(\mathrm{H}+\mathrm{L})$ was purchased from Zymed Laboratory, Inc. (California). Rabbit-anti rat Tf antiserum was purchased from Cappel (England).
Other reagents were obtained from commercial sources. Animals and Dosing Adult male Wistar strain rats (Imamichi rats, Nippon Bio-supp. Center, Tokyo, weight range, $200-220 \mathrm{~g}$ ) were treated with neat DBP as a single oral dose (mentioned below) after housing for one week in this study. Control rats received $0.9 \%$ saline $(1.0 \mathrm{ml})$.

General Procedure Nine rats received neat DBP $(8.6 \mathrm{mmol} / \mathrm{kg}$ body weight), the dose of which caused testicular atrophy within one week ${ }^{5)}$ and severe sloughing of mature germ cells at $6 \mathrm{~h}$ after the administration. ${ }^{6}{ }^{6}$ Six rats from each of the control and treated groups were killed at $3 \mathrm{~h}$ and the three remaining treated rats were sacrificed at $6 \mathrm{~h}$ to demonstrate the sloughing of germ cells.

Blood was collected from the abdominal aorta of the control and DBP-treated rats, and erythrocytes were isolated from the plasma by centrifugation at $1000 \times \boldsymbol{g}$ for $10 \mathrm{~min}$, washed three times with saline $(5 \mathrm{vol}$.$) , and$ subjected to biochemical examination, respectively. After the examination, the erythrocytes from the control rats were combined to use in the in vitro studies. Plasma for the in vitro studies was collected from the six control rats and diluted to $50 \%$ with $66 \mathrm{~mm}$ sodium phosphate $(\mathrm{pH}$ 7.4).

Urinary samples were collected at 3 and $6 \mathrm{~h}$ after administration and used to measure iron concentrations.

The right testes from the $3 \mathrm{~h}$ - and $6 \mathrm{~h}$-treated rats were subjected to biochemical examination and the left ones from the $6 \mathrm{~h}$-treated rats were subjected to histological examination.

A portion of the liver was fixed in $10 \%$ neutral buffered formalin and embedded in paraffin. After removal of paraffin, sections of the liver were stained with $2 \%$ potassium ferricyanide- $1 \% \mathrm{HCl}$ and $2 \%$ potassium ferrocyanide- $1 \% \mathrm{HCl}$, respectively. A portion of the remaining liver and spleen were used to isolate ferritin $(\mathrm{Ft})$ and $\mathrm{Hs}$ fractions as described below. 
The liver and spleen for in vitro studies were obtained from another two control rats and were used for the preparation of non-parenchymal liver cells and spleen cells, respectively.

MBP was used in concentrations ranging from 0.1 to $6.8 \mu \mathrm{mol}$ in the initial incubation-medium, since in the in vivo studies, MBP levels were $1.8 \mu \mathrm{mol} / \mathrm{ml}$ in the plasma and $90 \mathrm{nmol} / \mathrm{ml}$ in the $50 \%$-erythrocyte-suspension at $3 \mathrm{~h}$ after oral dosing of DBP $(8.6 \mathrm{mmol} / \mathrm{kg}){ }^{18)}$

Hematological Examination of Erythrocytes The number of erythrocytes and mean corpuscular volume (MCV) were measured using a Sysmex M-2000 equipped with Sysmex DA-1000 (Toa Iyodensi, Ltd., Japan).

Separation of Ft, Hs, and Tf Fractions in the Liver and Spleen Fractionations of $\mathrm{Hs}$ and $\mathrm{Ft}$ were carried out according to the methods of Vidnes and Helgeland, ${ }^{22)}$ and Setsuda, ${ }^{23)}$ respectively from both the liver and spleen. The liver was homogenized with distilled water (10 vol.). The homogenate was filtered and centrifuged at $600 \times \mathrm{g}$ at $4{ }^{\circ} \mathrm{C}$ for $15 \mathrm{~min}$ to give a sedimentary $\mathrm{Hs}$ fraction and supernatant ( $\mathrm{Tf}$ and $\mathrm{Hb}$ ) fraction. The sediment was washed with water $(3 \mathrm{ml})$ and the washed water was combined with the supernatants. After centrifugation at $10000 \times \mathrm{g}$ at $4{ }^{\circ} \mathrm{C}$ for $20 \mathrm{~min}$, a portion of the supernatant was heated at $75^{\circ} \mathrm{C}$ for $10 \mathrm{~min}$, followed by centrifugation at $5000 \times \boldsymbol{g}$ for $15 \mathrm{~min}$ to give a soluble fraction as $\mathrm{Ft}$ fraction. $^{22)}$

The spleen was homogenized with $0.15 \mathrm{M} \mathrm{NaCl}(4 \mathrm{vol})$. The homogenate was filtered and centrifuged at $5000 \times \mathbf{g}$ at $4{ }^{\circ} \mathrm{C}$ for $30 \mathrm{~min}$ to give a sedimentary $\mathrm{Hs}$ fraction and supernatant ( $\mathrm{Tf}$ and $\mathrm{Hb}$ ) fraction. The sediment was washed with $0.15 \mathrm{M} \mathrm{NaCl}(1 \mathrm{ml})$ and the washed solution was combined with the supernatants. A portion of the supernatant was heated at $75^{\circ} \mathrm{C}$ for $10 \mathrm{~min}$ and centrifuged at $5000 \times g$ at $4{ }^{\circ} \mathrm{C}$ for $15 \mathrm{~min}$ to give a solution. The solution was adjusted to $\mathrm{pH} 4.8$, centrifuged, and ammonium sulfate was added to reach $50 \%$. The mixture was then allowed to stand at $2-10^{\circ} \mathrm{C}$ for $18 \mathrm{~h}$, and centrifuged at $2500 \times \mathrm{g}$ at $4^{\circ} \mathrm{C}$ for $15 \mathrm{~min}$ to give a sedimentary fraction. The fraction was dissolved in $0.15 \mathrm{M}$ $\mathrm{NaCl}(1 \mathrm{ml})$ as $\mathrm{Ft}$ fraction. ${ }^{23)}$

The sedimentary Hs fraction was subjected to Hs-iron measurement. The supernatant was also subjected to the measurement of $\mathrm{Hb}$ and $\mathrm{Tf}$.

Measurement of Iron and $\mathbf{H b}$ Levels of non-heme iron and $\mathrm{Hb}$ were determined using an assay kit, Fe-mono Kainos (by the yellow-green complex formation method with 2-nitroso-5-( $N$-propyl- $N$-sulfopropylamino)phenol in the presence of a reducing agent, Kainos) and Hemoglobin B Test Wako (by sodium lauryl sulfate method, Wako Pure Chemicals), respectively.

Total iron binding capacity (TIBC) was determined by combining two assay kits, Fe-Kainos (the iron sequestered by $\mathrm{Tf}$ after the addition of ferrous iron, Kainos) and Fe-mono Kainos (Kainos). Each value represents an average of the duplicates.

Total iron in the blood, organs and fraction samples was digested completely with concentrated nitric acid $(1.0 \mathrm{ml}$; specific gravity 1.38 available for metal ions) at $110^{\circ} \mathrm{C}$ for $2 \mathrm{~d}$ and was then analyzed using a Hitachi atomic absorption spectrometer (Model 170-50) at $248.3 \mathrm{~nm}$.
Enzyme Immunoassay of $\mathrm{Tf}$ Tf was measured in duplicate samples by an enzyme immunoassay, according to the method of Fukuoka et al. ${ }^{6)}$ : The samples used were supernatants at $105000 \times g$ of the separated cell fraction mentioned above. Twenty $\mu \mathrm{g}$ of Tf was solubilized in $10 \mathrm{ml}$ of phosphate buffer containing saline (PBS; $134 \mathrm{~mm} \mathrm{NaCl}$ in $20 \mathrm{~mm}$ phosphate buffer, $\mathrm{pH}$ 7.3). Flat-bottomed polyvinyl microtitre plates (Nunc, Denmark) were coated with Tf in PBS by adding $100 \mathrm{ng}$ in $50 \mu \mathrm{l}$ buffer to each well. The plates were incubated at $20^{\circ} \mathrm{C}$ under cover for $2 \mathrm{~h}$ and washed with $0.1 \%$ Tween 20 in PBS (PBS-T). After four wash cycles, the plates were treated with samples or standard protein (Tf) preincubated with antiserum (1:20000) (rabbit anti-rat $\mathrm{Tf}$ ) in PBS. After incubation at $20^{\circ} \mathrm{C}$ for $2 \mathrm{~h}$ and four wash cycles with PBS-T, $50 \mu \mathrm{l}$ of a solution of horseradish peroxidase labelled goat-anti-rabbit IgG diluted $1: 1000$ in PBS-T and the plates were incubated at $20^{\circ} \mathrm{C}$ for $2 \mathrm{~h}$. Four wash cycles followed. Fifty $\mu \mathrm{l}$ of substrate solution $(10 \mu \mathrm{l}$ of $30 \% \mathrm{H}_{2} \mathrm{O}_{2}$ and $10 \mathrm{mg}$-tablet of ortho-phenylenediamine$\mathrm{HCl}$ in $25 \mathrm{ml}$ of citrate-phosphate buffer $(2.4 \mathrm{~mm}$ citric acid and $51 \mathrm{~mm} \mathrm{Na}_{2} \mathrm{HPO}_{4}, \mathrm{pH} 5.0$ )) was added to each plate. The plates were then incubated at $20^{\circ} \mathrm{C}$ for $30 \mathrm{~min}$ in darkness. The substrate solution was made immediately before use. The reaction was terminated after exactly $30 \mathrm{~min}$ by adding $50 \mu \mathrm{l}$ of $1.5 \mathrm{M} \mathrm{H}_{2} \mathrm{SO}_{4}$ to each well. The absorbance was measured at $492 \mathrm{~nm}$ in a Titertek Multiscan (Flow Laboratories).

Incubation of Rat Plasma with MBP The diluted plasma $(1 \mathrm{ml})$ was added in a solution of MBP in $5 \mathrm{mM}$ sodium phosphate-buffer ( $\mathrm{pH} \mathrm{8.0)}$ and the concentrations of MBP were adjusted at $0,0.1,0.3,0.7,1.4,3.4$ and $6.8 \mu \mathrm{mol}$ in the total mixture $(1.5 \mathrm{ml})$. The mixture was incubated at $37^{\circ} \mathrm{C}$ for $2 \mathrm{~h}$. A portion of the incubation mixture was used to measure TIBC and Tf-iron levels. The rest was passed through a disposable filter, Sartorius SM MW 20000, by centrifugation at $1000 \times \boldsymbol{g}$ for $10 \mathrm{~min}$. The filtrate was measured for levels in iron-containing proteins with a molecular weight less than 20000.

Preparation of NPC and SC NPC were isolated from rats by in situ perfusion of the liver with collagenase. The cells were separated into two fractions, parenchymal hepatocytes and non-parenchymal cells, by differential centrifugation according to the method of Shimaoka et al. ${ }^{24)}$

$\mathrm{SC}$ were isolated from the spleen of control rats according to the modified method of Mishell-Dutton ${ }^{25)}$ : The spleen was minced in Hank's solution $(12 \mathrm{ml})$, allowed to stand for $30 \mathrm{~min}$ at $25^{\circ} \mathrm{C}$, and then separated into the cell debris and a supernatant cell fraction. The supernatant cell fraction was used for incubation studies.

Effects of NPC on the Erythrocytes Isolated from Rats Administered DBP A suspension $(60 \mu \mathrm{l})$ of the erythrocytes $\left(1.3-1.7 \times 10^{5}\right.$ cell $\left./ \mu \mathrm{l}\right)$ from control rats was incubated with NPC $\left(2.5 \times 10^{5}\right.$ cells $)$ in L-15 medium $(1 \mathrm{ml})$ at $37^{\circ} \mathrm{C}$ for $120 \mathrm{~min}$. The mixture was centrifuged at $1000 \times \boldsymbol{g}$ for $10 \mathrm{~min}$ to give pellets and supernatant fractions. The supernatant fraction was subjected to the measurement of iron levels, and the pellets were lysed with $5 \mathrm{~mm}$ phosphate buffer (pH 8.0) $(1 \mathrm{ml})$ to measure $\mathrm{Hb}$ levels. 
Effect of NPC and/or Plasma on Erythrocytes Treated with MBP A suspension $(20 \mu \mathrm{l})$ of the erythrocytes $\left(9.0 \times 10^{6} / \mu 1\right)$ from control rats was incubated with MBP $(0.1,0.2,0.7,1.4,3.4$ and $6.8 \mu \mathrm{mol})$ in a solution of $66 \mathrm{~mm}$ sodium phosphate-5.5 mM glucose $(500 \mu \mathrm{l}, \mathrm{pH} 7.4)$ and $50 \%$ rat plasma in $66 \mathrm{~mm}$ sodium phosphate buffer $(\mathrm{pH} 7.4,500 \mu \mathrm{l})$ under conditions which formed Heinz bodies. ${ }^{18)}$ After incubation for $5 \mathrm{~min}$, NPC $(500 \mu \mathrm{l}$, $1.5 \times 10^{6}$ cells $/ \mathrm{ml}$ in $\mathrm{L}-15$ medium) were added into the above mixture and incubated at $37^{\circ} \mathrm{C}$ for $2 \mathrm{~h}$ (in the case without NPC, $500 \mu$ l of L-15 medium was added and incubated).

The incubation mixture was centrifuged at $1000 \times \boldsymbol{g}$ for 10 min to give sedimental and supernatant fractions. The supernatants were measured for iron concentration. The sediment was lysed with distilled water $(500 \mu \mathrm{l})$ and gave a lysed solution and ghost-pellets. The lysed solution was used to measure the levels of $\mathrm{Hb}$, free iron and low molecular protein-iron filtrated through Centrisarto SM13249 (Molecular weight, 20000, Sartorius, Japan). The ghost-cell debris was used to measure iron levels by an atomic absorption spectrometer.

Effect of SC on Erythrocytes Treated with DBP or MBP In Vivo Study: Erythrocytes were isolated from rats administered DBP and from the control rats as mentioned above. Twenty $\mu$ l of the washed erythrocytes $\left(6.0-7.0 \times 10^{4}\right.$ cells $\left./ \mu 1\right)$ was incubated with a suspension $(500 \mu \mathrm{l})$ of SC $\left(7.0-7.5 \times 10^{6} \mathrm{cells} / \mathrm{ml}\right)$ at $37^{\circ} \mathrm{C}$ for $2 \mathrm{~h}$.

In Vitro Study: An erythrocyte-suspension $(20 \mu \mathrm{l})$ from the control rats was incubated with a solution $(\mathrm{pH} 7.3)$ of MBP $(0,0.1,0.2,0.7,1.4,3.4$ or $6.8 \mu \mathrm{mol})$ in Hanks' solution $(1000 \mu \mathrm{l})$ with/without $50 \%$ plasma $(500 \mu \mathrm{l})$ at $37^{\circ} \mathrm{C}$ for $5 \mathrm{~min}$. To the mixture was the above suspension $(500 \mu \mathrm{l}, \mathrm{pH} 7.3)$ of $\mathrm{SC}$ added and the mixture was incubated at $37^{\circ} \mathrm{C}$ for $2 \mathrm{~h}$.

The above incubation mixture was centrifuged at $1000 \times \boldsymbol{g}$ for $10 \mathrm{~min}$ to give sedimentary and supernatant fractions. A portion of the supernatant was used to measure iron and Tf-iron levels. The rest was passed through a disposable filter, Sartorius SM MW 20000, by centrifugation at $1000 \times \boldsymbol{g}$ for $10 \mathrm{~min}$. The filtrate was measured for iron levels in both free-iron and ironcontaining protein with a molecular weight of less than 20000. The sediment was lysed with distilled water $(500$ $\mu \mathrm{l})$ and gave a lysed solution and ghost-cell debris. The lysed solution was used to measure levels of $\mathrm{Hb}$.

\section{RESULTS}

Histopathological Examinations A histopathological examination was carried out, since it was necessary to know whether the histopathological results were in accord with the previous data ${ }^{4,5}$ before this study was performed. The testes obtained from rats at $6 \mathrm{~h}$ postadministration showed sloughing of the germ cells in the DBP-treated rats, so it was then proved to be of use for a mechanical investigation of testicular damage.

Kupffer cells and $\mathrm{Hs}$ in the liver were not stained with two reagents which detected $\mathrm{Fe}(\mathrm{II})$ and $\mathrm{Fe}(\mathrm{III})$, respectively. However, protein-mass in the hepatic $\mathrm{Hs}$ fraction from DBP-treated rats and NPC-debris from DBP
(MBP)-affected erythrocytes were stained with the reagent for $\mathrm{Fe}(\mathrm{II})$ but not $\mathrm{Fe}(\mathrm{III})$. A stained blue colour was eluted from the protein mass into the reagent solution in course of time. This suggests that $\mathrm{Hb}$ might be decomposed or denaturated to ferrous proteins and that the proteins might not be fixed or might be washed out during the washing procedure on the liver-slide glass.

Hematological Examination Erythrocytes from DBPtreated rats showed no changes in mean corpuscular volume (MCV) when compared with that of the controls: $60.6 \pm 0.9 \mathrm{fl}$ for the control and $58.2 \pm 1.5$ for erythrocytes from DBP-treated animals.

Biochemical Examination Urinary iron levels were $0.03 \pm 0.01 \mu \mathrm{g}$ and $1.49 \pm 0.13 \mu \mathrm{g}$ for $3 \mathrm{~h}$ and $6 \mathrm{~h}$-control rats, respectively, and $0.26 \pm 0.06 \mu \mathrm{g}$ and $2.69 \pm 0.19 \mu \mathrm{g}$ in the $3 \mathrm{~h}$ and $6 \mathrm{~h}$-urine of DBP-treated rats, respectively. The excretion levels of iron were significantly higher $(p<0.01)$ in the treated rats than in the controls.

Table 1 shows rat body and organ weights. Of the organs, the liver, spleen and testes showed a trendency to decrease in weight, but it was not significant. The ratio of testes to body weight showed a significant decrease, in accord with the previous data. ${ }^{6,18)}$

Table 2 shows concentrations of iron and $\mathrm{Hb}$ in the blood, liver, spleen or right testis. Iron depletion was observed in the blood and testis of the treated rats. Iron levels in hepatic fractions showed significant increases in

Table 1. Weights of Body, Liver, Spleen and Testis at $3 \mathrm{~h}$ after Oral Administration of DBP

\begin{tabular}{lrc}
\hline \multicolumn{1}{c}{ Organ weight } & Control & \multicolumn{1}{c}{ Treated } \\
\hline Body & $217.0 \pm 2.9$ & $216.0 \pm 4.2$ \\
Liver & $11.5 \pm 0.7$ & $10.0 \pm 0.4$ \\
Liver $/$ body $\times 10^{-3}$ & $52.9 \pm 1.6$ & $46.3 \pm 2.9^{*}$ \\
Spleen $\times 10^{-1}$ & $6.0 \pm 0.3$ & $5.9 \pm 0.5$ \\
Spleen $/$ body $\times 10^{-4}$ & $25.7 \pm 1.5$ & $25.6 \pm 2.1$ \\
Right testis $\times 10^{-1}$ & $9.1 \pm 0.1$ & $8.5 \pm 0.4$ \\
Left testis $\times 10^{-1}$ & $9.2 \pm 0.1$ & $8.5 \pm 0.5$ \\
Testes $/$ body $\times 10^{-4}$ & $85.9 \pm 2.0$ & $78.2 \pm 1.3^{*}$ \\
\hline
\end{tabular}

Data are expressed as $g$ and are means \pm S.D. $(n=6)$; not significant except for asterisks. * Significant for $p<0.05$, compared with the respective controls; Dunnett-type mean rank test. ${ }^{38\}}$

Table 2. Levels of Iron and $\mathrm{Hb}$ after Oral Administration of DBP

\begin{tabular}{|c|c|c|c|}
\hline \multicolumn{2}{|c|}{ Blood and organs } & Control & Treated \\
\hline \multicolumn{4}{|c|}{ Total iron $(\mu \mathrm{g} / \mathrm{ml}$ blood or $\mathrm{g}$ organ $)$} \\
\hline \multirow{3}{*}{$\begin{array}{l}\text { Blood } \\
\text { Liver }^{a}\end{array}$} & & $624.1 \pm 3.9$ & $528.0 \pm 5.8^{* *}$ \\
\hline & Hs fraction & $6.3 \pm 0.2$ & $7.5 \pm 0.1^{*}$ \\
\hline & Tf fraction $\left.{ }^{b}\right)$ & $10.8 \pm 0.7$ & $7.9 \pm 0.6^{*}$ \\
\hline & Ft fraction & $0.6 \pm 0.02$ & $0.7 \pm 0.08$ \\
\hline \multirow[t]{3}{*}{ Spleen $^{a)}$} & Hs fraction & $3.5 \pm 0.4$ & $3.3 \pm 0.3$ \\
\hline & Tf fraction $\left.{ }^{b}\right)$ & $13.9 \pm 2.2$ & $18.7 \pm 3.6^{*}$ \\
\hline & Ft fraction & $41.4 \pm 4.1$ & $33.5 \pm 3.1$ \\
\hline \multicolumn{2}{|c|}{ Right testis } & $26.0 \pm 1.3$ & $20.4 \pm 0.5^{*}$ \\
\hline \multicolumn{4}{|c|}{$\mathrm{Hb}$} \\
\hline \multicolumn{2}{|c|}{ Blood (mg/ml) } & $186.5 \pm 6.2$ & $145.3 \pm 6.0^{*}$ \\
\hline \multicolumn{2}{|c|}{ Spleen $(\mathrm{mg} / \mathrm{ml})$} & $49.6 \pm 5.6$ & $18.6 \pm 3.5^{* *}$ \\
\hline
\end{tabular}

Values are means + S.D. $(n=6)$; not significant except for asterisks: $*$ significant for $p<0.05 ; * *$ significant for $p<0.01$, compared with the respective controls; Dunnett-type mean rank test. ${ }^{38)}$ a) The fractionation was carried out according to the Materials and Methods. b) Tf levels in the fractions were $8.4 \pm 0.2 \mathrm{mg}$ for the control liver and $5.7 \pm 0.4^{*} \mathrm{mg}$ for the treated liver, and $160.9 \pm 18.9 \mu \mathrm{g}$ for the control spleen and $173.0 \pm 12.7 \mu \mathrm{g}$ for the treated spleen. 
Table 3. Levels of $\mathrm{Tf}$ (TIBC) and Tf-Iron in the Plasma at $3 \mathrm{~h}$ after Oral Administration of DBP or $2 \mathrm{~h}$ Incubation with MBP

\begin{tabular}{lcc}
\hline \multicolumn{1}{c}{ Plasma } & Control & DBT-treated \\
\hline In vivo & & \\
TF $(\mathrm{TIBC}) \mu \mathrm{g} / \mathrm{dl}$ & $542.9 \pm 16.5$ & $636.2 \pm 35.6^{*}$ \\
Tf-iron $\mu \mathrm{g} / \mathrm{dl}$ & $294.3 \pm 68.3$ & $142.2 \pm 10.6^{*}$ \\
Saturation \% & $52.1 \pm 11.8$ & $23.7 \pm 2.9^{*}$ \\
In vitro & & \\
MBP & $0 \mu \mathrm{mol}$ & $6.8 \mu \mathrm{mol}$ \\
TIBC $\mu \mathrm{g} / \mathrm{dl}$ & $206.3 \pm 8.8$ & $209.9 \pm 14.7$ \\
TF-iron $\mu \mathrm{g} / \mathrm{dl}$ & $110.8 \pm 0.1$ & $105.0 \pm 5.8$ \\
Saturation \% & $63.8 \pm 13.1$ & $62.4 \pm 14.3$ \\
\hline
\end{tabular}

Values are means \pm S.D. $(n=6)$. In vitro experiment changes in TIBC and Tfiron levels were not observed at doses of $0.7-3.4 \mu \mathrm{mol}$ MBP in the medium when compared with the respective control (MBP $0 \mu \mathrm{mol}$ ). An iron-containing compound with a molecular weight of less than 20000 was not detectable in the medium. * Significant for $p<0.05$, compared with the respective controls; Dunnett-type mean rank test. ${ }^{38)}$

the Hs fraction and a decreasing tendency in the other fractions. Tf levels $(5.7 \pm 0.4 \mathrm{mg})$ in the $\mathrm{Tf}$ fraction of the treated rats showed significant decreases $(p<0.05)$ when compared with those $(8.4 \pm 0.2 \mathrm{mg})$ of the controls. In the spleen, total iron levels showed a significant increase in the Tf fraction, although its $\mathrm{Tf}$-levels did not change $(160.9 \pm 18.9 \mu \mathrm{g}$ for control; $173.0 \pm 12.7 \mu \mathrm{g}$ for the treated rats).

$\mathrm{Hb}$ levels showed significant decreases in the blood and spleen. $\mathrm{Hb}$ levels in the liver were eliminated in the table because its levels varied by bleeding upon liver removal.

Table 3 shows plasma Tf (TIBC) and Tf-iron levels in the in vivo and in vitro studies. In in vivo studies, the TIBC in DBP-treated rat was higher, and its Tf-iron levels and the saturation ratio of $\mathrm{Tf}$ with iron were significantly lower, when compared with those of the controls, respectively. In in vitro studies, MBP, a metabolite of DBP, did not affect the levels in TIBC and Tf-iron up to the dose of $6.8 \mu \mathrm{mol}$.

Table 4 shows the effects of NPC and SC on the erythrocytes (RBC) from control and DBP-treated rats. As for the effects of NPC, the $\mathrm{Hb}$ ratio of post- to pre-incubation showed a significant decrease in RBC from the DBPtreated rats when compared with those in the control cells. Iron levels in the medium and the cell debris were higher in the RBC of DBP-treated rats than in those of the controls. This suggests that iron was released from the $\mathrm{Hb}$ of the DBP-affected erythrocytes and a portion of the iron was accumulated in the cell debris.

As for the effect of SC, a significant increase in both $\mathrm{Hb}$ levels and the $\mathrm{Hb}$ ratio was observed in the DBPaffected erythrocytes, without a change in the release of iron from $\mathrm{Hb}$, when compared with those of the control. This suggests that the DBP-affected erythrocytes might resist being destroyed by $\mathrm{SC}$ or that iron might be released from components of the SC.

Table 5 shows the effects of the plasma Tf, NPC and $\mathrm{SC}$ on $\mathrm{Hb}$ and iron levels in erythrocytes exposed to MBP.

On incubation of the erythrocytes with MBP and plasma, the plasma Tf-iron levels increased at $3.4 \mu \mathrm{mol}$ of MBP, and a decrease in $\mathrm{Hb}$ levels was observed at 6.8 $\mu \mathrm{mol}$ without changes in iron levels in the ghost. These
Table 4. Effect of NPC or SC on Erythrocytes (RBC) from the Control and DBP-Treated Rats

\begin{tabular}{|c|c|c|}
\hline Cells & Control & DBP-treated \\
\hline \multicolumn{3}{|l|}{ NPC } \\
\hline \multicolumn{3}{|l|}{$\mathrm{Hb} \mathrm{pg} / \mathrm{RBC}$} \\
\hline before incubation & $25.5 \pm 1.0$ & $21.5 \pm 0.8^{*}$ \\
\hline after $2 \mathrm{~h}$ incubation & $23.7 \pm 0.2$ & $18.6 \pm 0.7^{*}$ \\
\hline \multicolumn{3}{|l|}{$\mathrm{Hb}$ ratio of the post- } \\
\hline to the pre-incubation $(\%)$ & $92.5 \pm 0.7$ & $86.5 \pm 0.8^{*}$ \\
\hline $\begin{array}{l}\text { Iron }(\mathrm{ng} / \mathrm{ml}) \text { in the medium } \\
\text { after } 2 \mathrm{~h} \text { incubation }\end{array}$ & $51.5 \pm 2.5$ & $89.4 \pm 0.1 * *$ \\
\hline Cell-debris $\left(\times 10^{-1} \mathrm{mg}\right)$ & $20.4 \pm 0.3$ & $24.2 \pm 0.6^{*}$ \\
\hline Iron in the debris $\left(\times 10^{-1} \mu \mathrm{g}\right)$ & $55.6 \pm 0.4$ & $66.7 \pm 0.2^{*}$ \\
\hline \multicolumn{3}{|l|}{$\mathrm{SC}$} \\
\hline \multicolumn{3}{|l|}{$\mathrm{Hb} \mathrm{pg/RBC}$} \\
\hline after $2 \mathrm{~h}$ incubation & $11.7 \pm 0.5$ & $13.7 \pm 0.2^{*}$ \\
\hline $\begin{array}{l}\text { Hb ratio of the post- } \\
\text { to the pre-incubation }(\%)\end{array}$ & $49.3 \pm 1.6$ & $67.4 \pm 2.5^{*}$ \\
\hline $\begin{array}{l}\text { Iron }(\mathrm{ng} / \mathrm{ml}) \text { in the medium } \\
\text { after } 2 \mathrm{~h} \text { incubation }\end{array}$ & $252.4 \pm 37.3$ & $253.5 \pm 36.7$ \\
\hline
\end{tabular}

Values are means \pm S.D. $(n=6) . \quad *$ Significant for $p<0.05 ; * *$ significant for $p<0.01$, compared with the respective controls; Dunnett-type mean rank test. ${ }^{38}$ )

suggest that $\mathrm{Tf}$ might catch iron released from the $\mathrm{Hb}$ of the MBP-affected erythrocytes.

When NPC existed in the incubation medium, $\mathrm{Hb}$ levels decreased and iron levels in the cell debris increased at $6.8 \mu \mathrm{mol}$ of MBP, significantly, but Tf-iron levels in the medium did not change. The results suggest that the MBP-affected erythrocytes might be destroyed by NPC and the released iron might be accumulated into the debris of NPC and/or the ghost.

When NPC was replaced with SC, the Hb levels were not affected by up to $6.8 \mu \mathrm{mol}$ of MBP. However, there was observed an increase in Tf-iron and decreases in free iron and/or low molecular protein-iron at the range of $0.7-6.8 \mu \mathrm{mol}$. Yet, when plasma did not exist in the medium, the $\mathrm{Hb}$ levels descended significantly at $6.8 \mu \mathrm{mol}$ and the iron increased ascendingly in the medium at the ranges from 0.7 to $6.8 \mu \mathrm{mol}$. These results suggest the possibility that MBP might induce the release of iron from components of SC, and that the released iron may be captured to plasma-Tf.

\section{DISCUSSION}

Mechanisms of iron depletion have been investigated partially from the metabolism of $\mathrm{Hb}$ and iron in the liver, spleen and bone marrow ${ }^{18,19)}$ : DBP was metabolized to MBP, and MBP might then accelerate the dissociation of $\mathrm{Hb}$ and $\mathrm{Tf}$ and the accumulation of the iron in the liver and spleen, along with the depletion of $\mathrm{Hb}$ and iron in bone marrow. It was necessary to determine which would be depleted first from circulating iron, $\mathrm{Tf}$ or $\mathrm{Hb}$, by MBP in liver and spleen cells. In the in vivo studies, since there was observed a loss of Tf-iron in the liver, accompanied by the enhancement of iron as Hs-iron (Table 2), the loss might be attributed to the depletion of iron in the plasma Tf (Table 3). The in vitro studies showed the possibility that iron was released from MBP-affected erythrocytes (Table 5) but not from the plasma Tf (Table 3), and that the released iron was caught by Tf, not the ghost (Table 
Table 5. Effects of MBP on the Erythrocytes (RBC) in the Plasma, NPC and SC

\begin{tabular}{|c|c|c|c|c|c|}
\hline MBP in medium & $0 \mu \mathrm{mol}^{a)}$ & 0.7 & 1.4 & 3.4 & 6.8 \\
\hline \multicolumn{6}{|l|}{$2 \mathrm{~h}$ incubation with rat plasma } \\
\hline $\mathrm{Hb} \mathrm{pg} / \mathrm{RBC}$ & $22.6 \pm 2.4$ & $19.6 \pm 3.8$ & $22.6 \pm 1.0$ & $20.6 \pm 1.0$ & $19.2 \pm 0.9 *$ \\
\hline Tf-iron in the medium $(\mu \mathrm{g} / \mathrm{dl})$ & $84.0 \pm 2.2$ & $86.2 \pm 1.8$ & $91.3 \pm 4.3$ & $96.5 \pm 2.4^{*}$ & $99.8 \pm 3.1^{*}$ \\
\hline Iron in the ghost $(\mu \mathrm{g} / \mathrm{dl})$ & $28.3+1.3$ & $24.0+2.0$ & $25.5+2.0$ & $29.8+3.7$ & $28.9+1.1$ \\
\hline \multicolumn{6}{|l|}{$2 \mathrm{~h}$ incubation with NPC and plasma } \\
\hline $\mathrm{Hb} \mathrm{pg} / \mathrm{RBC}$ & $20.4 \pm 0.8$ & $20.5 \pm 1.0$ & $19.3 \pm 1.1$ & $17.9 \pm 1.2$ & $16.6 \pm 0.8^{*}$ \\
\hline Tf-iron in the medium $(\mu \mathrm{g} / \mathrm{dl})$ & $83.7 \pm 1.8$ & $82.5 \pm 2.5$ & $83.5 \pm 2.5$ & $82.6 \pm 3.2$ & $81.3 \pm 3.7$ \\
\hline Iron in the cell debris $(\mathrm{ng} / \mathrm{ml})$ & $3.8 \pm 0.4$ & $4.2 \pm 1.0$ & $4.5 \pm 0.9$ & $5.3 \pm 1.2$ & $9.8 \pm 1.2^{*}$ \\
\hline \multicolumn{6}{|l|}{$2 \mathrm{~h}$ incubation with $\mathrm{SC}$ and plasma } \\
\hline $\mathrm{Hb} \mathrm{pg} / \mathrm{RBC}$ & $17.7 \pm 0.9$ & $19.0 \pm 0.8$ & $18.8+1.0$ & $19.4 \pm 0.9$ & $17.4+0.7$ \\
\hline Tf-iron in the medium $(\mu \mathrm{g} / \mathrm{dl})$ & $72.2 \pm 0.7$ & $80.4 \pm 3.1 * *$ & $80.4 \pm 2.2^{* *}$ & $80.5 \pm 3.2 * *$ & $80.7 \pm 1.7^{* *}$ \\
\hline LMP-iron $^{b)}$ in the medium $(\mathrm{ng} / \mathrm{ml})$ & $22.6 \pm 1.8$ & $12.5 \pm 1.1^{* *}$ & $12.2 \pm 1.0^{* *}$ & $12.2 \pm 1.7^{* *}$ & $11.0 \pm 0.5^{* *}$ \\
\hline \multicolumn{6}{|l|}{$2 \mathrm{~h}$ incubation with $\mathrm{SC}$} \\
\hline $\mathrm{Hb} \mathrm{pg} / \mathrm{RBC}$ & $23.8 \pm 1.2$ & $23.2 \pm 1.5$ & $23.2 \pm 1.4$ & $20.6 \pm 1.6$ & $19.1 \pm 1.2^{*}$ \\
\hline Iron released into medium $(\mathrm{ng} / \mathrm{ml})$ & $16.2 \pm 0.3$ & $32.8 \pm 4.9^{*}$ & $38.3 \pm 7.1^{* *}$ & $52.5 \pm 5.2^{* *}$ & $.53 .9 \pm 4.3^{* *}$ \\
\hline
\end{tabular}

* Significant for $p<0.05 ; * *$ significant for $p<0.01$, compared with the respective controls; Dunnett-type mean rank test. ${ }^{38)}$ Values are means \pm S.D. $(n=6)$. a) When erythrocytes were incubated with MBP at doses of $0.1,0.2$ and $0.4 \mu \mathrm{mol}$, the results showed no significant difference from those of the respective controls $(0 \mu \mathrm{mol})$. The data at $0.1-0.4 \mu \mathrm{mol}$ were omitted from this table. b) LMP-iron represents a mixture of free iron and iron-containing proteins with molecular weights less than 20000.

5). Therefore, it was conceivable that the erythrocytes might be destroyed by the liver Kupffer cells and that the iron might be released from the $\mathrm{Hb}$ and accumulate in the hepatic Hs fraction, resulting in part in iron-depletion in the blood (Table 2).

The accumulation of iron in the Hs fraction (Table 2) in the in vivo studies was in accord with the results obtained by the in vitro studies, in which NPC seemed to destroy the erythrocytes from DBP-treated rats and the iron was captured in the cell debris of NPC (Table 4). Similarly, when erythrocytes were preincubated with MBP and then incubated with NPC, iron released from the $\mathrm{Hb}$ was accumulated in the cell debris of NPC, not to Tf (Table 5). When NPC did not exist in the incubation medium, the iron was captured to Tf (not in the ghost) (Table 5). This suggested that the released iron might be oxidized in order to be captured to Tf. The released iron existed as $\mathrm{Fe}^{2+}$-proteins in both the cell-debris and Hs fraction (see the Results). Furthermore, it has been shown that the $\mathrm{Fe}^{2+}$ ion is not caught or binds weakly to $\mathrm{Tf}^{26-29)}$

As for SC, it seemingly destroyed the erythrocytes from the control rats much more than those from DBP-treated animals, accompanied by capture of the released iron to Tf (Table 2). The iron of senescent erythrocytes in the spleen was utilized in the bone marrow to reticulocytes for the biosynthesis of $\mathrm{Hb}^{30)}$ via $\mathrm{Tf}$-iron. However, in vitro studies suggested that the enhancement of Tf-iron might not contribute to the decomposition of the $\mathrm{Hb}$. MBP might release iron from a component of SC (Table 5). When erythrocytes were exposed to MBP at the range of 0.3 to $3.4 \mu \mathrm{mol}$, the $\mathrm{Hb}$ was not decomposed by incubation with $\mathrm{SC}$, irrespective of the existence of plasma. Nevertheless, increases in iron were observed in the medium and in the Tf when added the plasma. Although further study remains to determine whether MBP releases iron from a component of SC directly or indirectly by macrophages, it is conceivable that the DBP- or MBP-affected erythrocytes might be destroyed mainly by NPC rather than SC.

Normal erythrocytes undergo autooxidation to a small extent (about $1 \%$ of the total $\mathrm{Hb}$ ) with the methemoglobin $(\mathrm{MetHb})$ formed converted back to functional $\mathrm{Hb}$ by
MetHb reductase. ${ }^{31)}$ The activity of the reductase showed a trendency to decrease in the DBP- or MBP-affected erythrocytes, accompanied by significant decreases in glutathion (GSH) levels and in GSH reductase activity. ${ }^{18)}$ It is known that autooxidation represents the initial reaction that is followed by reactions destructive not only to $\mathrm{Hb}$ but also to other components of the erythrocytes ${ }^{32)}$ during hemichrome formation, protein denaturation and Heinz body formation (including cell aging). ${ }^{31)}$ DBP or MBP might induce abnormal $\mathrm{Hb}$ by autooxidation due to the acidic microenvironment of MBP. ${ }^{18)}$ The rate of autooxidation significantly increases by a decrease in the $\mathrm{pH}$ value of the medium probably due to the protonation of the distal histidine of $\mathrm{Hb}^{\left.3{ }^{33}\right)}$ Considering that a Heinz body-like formation was observed with a higher incidence in both the arterial erythrocytes from DBP-treated rats ${ }^{18)}$ than the venous ones (unpublished data, not significant changes to the respective controls) and in the MBPaffected erythrocytes on air-bubbling (but not observed on non-bubbling), ${ }^{18)}$ it is conceivable that DBP or MBP might accelerate the autooxidation of $\mathrm{Hb}$ for progressive iron release accompanied by the depletion of GSH.

Since it was observed in this study that $\mathrm{Hb}$ was destroyed to insoluble $\mathrm{Fe}^{2+}$-proteins in the NPC (liver Kupffer cells) and then a portion of the released iron was finally excreted to the urine, the decomposition of $\mathrm{Hb}$ might contribute to the depletion of circulating iron by combination with the previous results ${ }^{18)}$ in which MBP might induce iron-deficient erythrocytes in the blood.

It has also been shown that DEHP depleted $\mathrm{Hb}$ in mice and rats ${ }^{34,35)}$ and that the autooxidation was induced by other compounds which induced testicular atrophy, such as nitrobenzene ${ }^{36)}$ and phenacetin. ${ }^{37)}$

In conclusion, this study proposes a possible mechanisms causing the depletion of circulating iron. Erythrocytes exposed to DBP and MBP might be decomposed in the NPC (liver Kupffer cells), being predominant over $\mathrm{SC}$, and the released iron might be accumulated in the NPC-debris as insoluble $\mathrm{Fe}^{2+}$-proteins.

Acknowledgement The authors are grateful to Dr. 
Michio Satoh for his advice on computer programming during the course of this work.

\section{REFERENCES AND NOTES}

1) Present address: School of Pharmaceutical Sciences, University of Shizuoka, Yata 52-1, Shizuoka 420, Japan

2) Creasy D. M., Foster J. R., Foster P. M. D., J. Pathol., 139, 309 (1983).

3) Foster P. M. D., Foster J. R., Cook M. W., Thomas L. V., Gangolli S. D., Toxicol. Appl. Pharmacol., 63, 120 (1982).

4) Fukuoka M., Tanimoto T., Zhou Y., Kawasaki N., Tanaka A., Ikemoto I., Machida T., J. Appl. Toxicol., 9, 277 (1989).

5) Fukuoka M., Zhou Y., Tanaka A., Ikemoto I., Machida T., J. Appl. Toxicol., 10, 285 (1990).

6) Fukuoka M., Kobayashi T., Zhou Y., Hayakawa T., J. Appl. Toxicol., 13, 241 (1993).

7) Zhou Y., Fukuoka M., Tanaka A., J. Appl. Toxicol., 10, 447 (1990).

8) Gangolli S. D., Environ. Health Perspect., 45, 77 (1982).

9) Gray T. J. B., Gangolli S. D., Environ. Health Perspect., 65, 229 (1986).

10) Oishi S., Toxicol. Lett., 66, 47 (1993).

11) Gray T. J. B., Beamand J. A., Food Chem. Toxicol., 22, 123 (1984).

12) Sjoberg P., Bondesson N. U., Gray T. J. B., Ploen L., Acta Pharmacol. Toxicol., 58, 225 (1986).

13) Dostal L. A., Chapin R. E., Stefanski S. A., Harris M. W., Schwetz B. A., Toxicol. Appl. Pharmacol., 95, 104 (1988).

14) Foster P. M. D., Thomas L. V., Cook M. W., Walters D. G., Toxicol. Lett., 15, 265 (1983).

15) Chapin R. E., Gray T. J. B., Phelps J. L., Dutton S. L., Toxicol. Appl. Pharmacol., 92, 467 (1988).

16) Gray T. J. B., Rowland I. R., Foster P. M. D., Gangolli S. D., Toxicol. Lett., 11, 141 (1982).

17) Thysen B., Morris P. L., Gatz M., Bloch E., Toxicol. Appl. Pharmacol., 106, 154 (1990).
18) Fukuoka M., Kobayashi T., Hayakawa T., Biol. Pharm. Bull., 17, 1609 (1994).

19) Fukuoka M., Kobayashi T., Hayakawa T., J. Appl. Toxicol., 15, 379 (1995).

20) Naughton B. A., Dornfest B. S., Bush M. E., Carlson C. A., Lapin D. M., J. Lab. Clin. Med., 116, 498 (1990).

21) Brunel R. F., J. Am. Chem. Soc., 45, 1334 (1923).

22) Vidnes A., Helgeland L., Biochim. Biophys. Acta., 328, 365 (1973).

23) Setsuda T., Acta Haemotol. Jpn., 48, 155 (1985).

24) Shimaoka S., Nakamura T., Ichihara A., Exp. Cell Res., 172, 228 (1987).

25) Mishell R., Dutton R., J. Exp. Med., 126, 423 (1967).

26) Carver F. J., Frieden E., Biochemistry, 17, 167 (1978).

27) Kojima N., Bates G., J. Biol. Chem., 254, 8847 (1979).

28) Harris D. C., Rinehart A. L., Herald D., Schwartz R. W., Burke F. P., Salvador A. P., Biochim. Biophys. Acta, 838, 295 (1985).

29) Brieland J. K., Clarke S. J., Karmiol S., Phan S. H., Fantone J. C., Arch. Biochem. Biophys., 294, 265 (1992).

30) Hemmaplardh D., Morgan E. H., Biochim. Biophys. Acta, 373, 84 (1974).

31) Wallace W. J., Maxwell J. C., Caughey W. S., Biochem. Biophys. Res. Commun., 57, 1104 (1974).

32) Wallace W. J., Houtchen R. A., Maxwell J. C., Caughey W. S., J. Biol. Chem., 257, 4966 (1982).

33) Zavodnik I. B., Piletskaia T. P., Stepuro I. I., Mol. Biol. Mosk., 26, 321 (1992)

34) Calley D., Autian J., Guess W. L., J. Pharm. Sci., 55, 158 (1966).

35) Gray T. J. B., Butterworth K. R., Gaunt I. F., Grasso P., Food Cosmet. Toxicol., 14, 389 (1977).

36) Mitsumori K., Kodama Y., Uchida O., Takada K., Saito M., Naito K., Tanaka S., Kurokawa Y., Usami M., Kawashima K., Yasuhara K., Toyoda K., Onodera H., Furukawa F., Takahashi M., Hayashi Y., J. Toxicol. Sci., 19, 141 (1994).

37) Gallemann D., Eyer P., Bio. Chem. Hoppe. Seyler., 374, 51 (1993).

38) Gad S. C., Weil C. S., "Principles and Methods of Toxicology," ed. by Hayes A. W., Raven Press, New York, 1982, pp. 273-320. 